\title{
Cartilage specific collagen activates macrophages and the alternative pathway of complement: evidence for an immunopathogenic concept of rheumatoid arthritis
}

\author{
H. M. HANAUSKE-ABEL, ${ }^{1}$ B. F. PONTZ, ${ }^{1 *}$ AND \\ H. U. SCHORLEMMER ${ }^{2}$
}

From the ${ }^{1}$ Kinderklinik and ${ }^{2}$ Institut für Med. Mikrobiologie, Johannes Gutenberg-Universität, 6500 Mainz, Federal Republic of Germany

SUMMARY We studied the effect of human interstitial collagen types I, II, and III on serum-free cultured mouse macrophages and on the complement classical and alternative pathways in human and guinea-pig serum. Type II collagen produced a dose-dependent consumption and conversion of C3 and factor B both in the homologous and in the heterologous system. This effect on the alternative pathway was reproduced in genetically $\mathrm{C} 4$-deficient guinea-pig serum and could be triggered by native, triple helical type $\Pi$ molecules, by their component $\alpha$ chains, and the $\mathrm{CNBr}$ peptide mixture. Addition of type II collagen to the mouse macrophage cultures induced not only a dose- and time-dependent secretion of lysosomal enzymes, but also the generation of a supernatant factor cytotoxic for mouse mastocytoma P 815 cells. Collagen of types I and III were conspicuously less active or inactive in all assays. The studies demonstrate properties of the collagen specific for cartilage which, on a molecular level, suggest its direct, local participation in the production and perpetuation of rheumatoid arthritis.

During the last decade one of the breakthroughs in the biochemistry of the intercellular matrix has been the demonstration that 'collagen' consists of several genetically distinct proteins with varied distribution in developing, adult, and pathological tissues. To date at least 5 trimeric, triple-helical collagen types have been identified and characterised as $[\alpha 1]_{3}$ or $[\alpha 1]_{2} \alpha 2 .^{1}$ In this group the interstitial types I, II,

\footnotetext{
Accepted for publication 11 March 1981.

Correspondence to Dr H. M. Hanauske-Abel, Kinderklinik, Johannes Gutenberg-Universität, D-6500 Mainz, Federal Republic of Germany.

*Present address: Max-Planck-Institut für Biochemie, Abt. für Bindegewebsforschung, München-Martinsried, FRG.

A preliminary account of parts of this work was presented at the Eighth International Complement Workshop, 13-16 October 1979, Key Biscane, Florida, USA.

Abbreviations used in this paper: APC, alternative pathway of complement; LDH, lactate dehydrogenase. CNBr, cyanogen bromide; $\mathrm{NADH}_{2}, \beta$-nicotineamide-adeninedinucleotide, reduced; EDTA, ethylenediaminetetra-acetic acid; DEAE, diethylaminoethyl; CM, carboxymethyl; SDSPAGE, sodium dodecyl sulphate polyacylamide gel electrophoresis.
}

and III are best characterised with respect to purification, alignment of type-specific $\mathrm{CNBr}$-peptides, composition, and sequence of aminoacids as well as the immunological behaviour. ${ }^{1}$

In vivo type II collagen was the first homologous protein antigen that did not require complete Freund's adjuvant for the induction of an autoimmune response characterised by high antibody titres and cellular sensitivity. This unique immunogenicity of type II is thought to account for its arthritogenic properties in rats: intradermal injection of native cartilage collagen causes a chronic synovitis with secondary erosion of articular cartilage and subchondral bone. ${ }^{2-4}$ Cells from sensitised donors are capable of passively transferring this response. ${ }^{5}$ The application of types I and III does not trigger an autoaggressive reaction. That is why type II collagen-provoked arthritis has been suggested as an appropriate model for rheumatoid arthritis in man. ${ }^{3}$ A similar type II collagen-induced arthritis can be produced in mice. ${ }^{6}$

In patients suffering from rheumatoid arthritis 
activation of the complement system obviously plays an important role by releasing phlogogenic peptides and proteins. Involvement of the classical pathway is evident by the reduction of individual components and concomitant demonstration of immune complexes in synovial effusions, ${ }^{7}$ while diminished concentrations of factor $B$ and properdin point to the participation of the alternative pathway. ${ }^{8}$ Exclusive activation of the alternative pathway is shown in the synovial fluid of arthritic patients with Bruton-type agammaglobulinaemia. ${ }^{9}$

The present study was carried out to investigate the interaction of purified interstitial collagen with the alternative pathway of complement and with macrophages.

\section{Materials and methods}

Experimental animals. Male mice (outbred strain NMRI/Bom) were purchased from G. L. Bomholtgard, Ry, Denmark.

Tissue culture materials. Tissue culture grade Petri dishes were obtained from Nunc $\mathrm{GmbH}$, Wiesbaden, Germany, fetal bovine serum and the TC 199 media from Flow Laboratories GmbH, Bonn, Germany.

Biochemical reagents. Penicillin and streptomycin were from Flow Laboratories $\mathrm{GmbH}$, Bonn, Germany, pyruvate and $\beta$-nicotinamide-adeninedinucleotide from Boehringer $\mathrm{GmbH}$, Mannheim, Germany, phenolphtalein glucuronic acid from Sigma GmbH, Munich, Germany, p-nitrophenyl2 -acetamido- $\beta$-D-desoxyglucopyranoside from Koch-Light Laboratories, Colnbrook, UK, preservative free heparin from Nordmark Werke $\mathrm{GmbH}$, Hamburg, Germany, and Triton X-100 from Serva GmbH, Heidelberg, Germany. The Limulus test (Pyrogent) was purchased from Byk-Mallinckrodt, Dietzenbach, Germany, the Protease Detection Kit from Bio-Rad, Munich, Germany.

Incubation for C3 activation and haemolytic assay for C3 activity. Standard incubation mixtures for C3 activation and the assay for haemolytic C3 measurement were performed as detailed by Bitter-Suermann et al. ${ }^{10}$ Equal volumes of either pooled normal or C4-deficient guinea-pig serum were incubated with appropriate dilutions of the test materials for $30 \mathrm{~min}$ at $37^{\circ} \mathrm{C}$ and cooled to $4^{\circ} \mathrm{C}$ in an ice bath; the concentrations of the collagen types referred to in the text represent final concentrations in this standard incubation mixture $(\mu \mathrm{g} / \mathrm{ml})$. Controls were run with water instead of test materials. From the standard incubation mixture samples were withdrawn and subdiluted to a final serum concentration of $1: 100$, $1: 500$, and $1: 1000$. The amount of residual haemolytically active C3 (site forming units; SFU) was determined and calculated as previously described. ${ }^{10}$
The values obtained were expressed as percentages of the haemolytically active $\mathrm{C} 3$ in the controls. The C3 content of normal and C4-deficient guinea-pig serum in the controls was in the range of $1-2 \times 10^{11}$ $\mathrm{SFU} \mathrm{C} 3 / \mathrm{ml}$.

Haemolytic assay for C1, C2, and C4 astivity. Haemolytic C1, C2, and C4 activities were assayed by the method of Müller et al. ${ }^{11}$

Immunoelectrophoretic analysis. Agarose ( $1 \%$ ) containing $10^{-2} \mathrm{M}$ EDTA was used in all experiments. Electrophoretic separation was performed at $\mathrm{pH} \mathrm{8.6}$ with 9 volts $/ \mathrm{cm}$ for $120 \mathrm{~min}$. $10 \mu \mathrm{l}$ samples of the standard incubation mixtures were used. After fixation the slides were stained with Coomassie brilliant blue $R$ 250. Antisera were a gift from Professor Bitter-Suermann (Mainz).

Macrophage collection, culture, and stimulation. Mouse macrophages were obtained by peritoneal lavage with $5 \mathrm{ml}$ TC 199 containing penicillin/ streptomycin (100 units/ml) and $10 \mathrm{IU} / \mathrm{ml}$ heparin. $2 \mathrm{ml}$ aliquots of this peritoneal exudate cell suspension $\left(0 \cdot 5-1 \cdot 0 \times 10^{6}\right.$ cells $\left./ \mathrm{ml}\right)$ were cultured in Petri dishes (diameter $35 \mathrm{~mm}$ ) and incubated in a humidified atmosphere of $5 \% \mathrm{CO}_{2}$ at $37^{\circ} \mathrm{C}$ for 2 hours to allow attachment of adherent cells. After vigorously washing 4 times with phosphate buffered saline, the cells were cultured in serum-free TC 199. Macrophages prepared in this way give a sheet of well spread cells within 24 hours. For in-vitro activation the dissolved test materials were added to the concentrations indicated. After the test period macrophages and supernates were collected and checked for enzyme secretion and cylotoxicity. In all experiments triplicate and quadruplicate cultures were used. The results obtained are expressed as the mean and standard deviation.

Enzyme assays. At the end of the test periods the medium was removed and the adherent cells were washed once with phosphate buffered saline. The cells were then released by adding saline containing $0 \cdot 1 \%(w / v)$ Triton X-100, and scraped off with a sterile rubber 'policeman.' The activity of the various enzymes were tested in media and cells. All assays were conducted under conditions that provide for the linear release of the products in relation to the amount of test sample and the time of incubation. Lactate dehydrogenase was assayed by determining the rate of oxidation of $\mathrm{NADH}_{2}$ at $340 \mathrm{~nm} .^{12}$ The representative lysosomal enzymes $\beta$-glucuronidase and $\mathrm{N}$-acetyl- $\beta$-D-glucosaminidase were assayed by the method of Stephens et al. ${ }^{13}$

Method of cytotoxicity assay. As the release of lactate dehydrogenase into the culture supernate is in indication of cell death, the ${ }^{51} \mathrm{Cr}$ release assay was replaced by the determination of LDH. The 2 
competitive methods-LDH or ${ }^{51} \mathrm{Cr}$ release-were compared in cytotoxicity studies, and the $\mathrm{LDH}$ release technique was found to be as sensitive and precise as the radioactive assay. ${ }^{14}$ The assay for the cytoplasmic LDH was conducted under conditions giving linear product release with respect to sample amount and incubation time; LDH was determined as given in Bergmeyer and Bernt. ${ }^{12}$ In positive experiments up to $90 \%$ of the cellular LDH content appeared in the supernate within 2 hours of incubation; that is why this time interval was chosen as test period. Control supernatants showed very low spontaneous background release of LDH even after 6 hours.

Cytotoxicity assay of supernates from stimulated macrophages. P815 cells, derived from a chemically induced mouse mastocytoma, served as targets. Unstimulated mouse macrophages cultured under serum-free conditions in the presence of the indicated collagen type II concentrations were used as effectors. Supernates were harvested at the given intervals. $5 \times 10^{5}$ target cells in $0.1 \mathrm{ml}$ of medium were mixed with $0.1 \mathrm{ml}$ of the culture supernatants in round bottomed plastic tubes. The tubes were filled with air containing $5 \% \mathrm{CO}_{2}$. After incubation at $37^{\circ} \mathrm{C}$ for 2 hours $0.8 \mathrm{ml} \mathrm{TC} 199$ was added to the tubes, the cells were centrifuged, and $0 \cdot 1 \mathrm{ml}$ samples of this supernate tested for $\mathrm{LDH}$ release. The percentage of $\mathrm{LDH}$ release is given relative to that of target cells exposed to medium from nonstimulated macrophages; this value did not differ significantly from that observed with target cells alone. The values presented are means of triplicate experiments.

Preparation of type I collagen. Adult human dura mater, obtained at necropsy, was freed from the great vessels, homogenised, and incubated with pepsin at $10 \mathrm{mg} / \mathrm{ml}, \mathrm{pH} 2 \cdot 8,15^{\circ} \mathrm{C}$. After 24 hours the initial amount of pepsin was added, the $\mathrm{pH}$ readjusted, and the digestion allowed to continue for another 24 hours at $15^{\circ} \mathrm{C}$. After centrifugation the supernatant was dialysed against $0.02 \mathrm{M}$ $\mathrm{Na}_{2} \mathrm{HPO}_{4}$; the deposit was dissolved in $0 \cdot 1 \mathrm{M}$ acetic acid and treated by a modification of the method outlined by Epstein. ${ }^{15}$ The $2.5 \mathrm{M} \mathrm{NaCl}$ precipitate was reprecipitated and then extracted with $1.5 \mathrm{M}$ $\mathrm{NaCl}, 0.05 \mathrm{M}$ Tris- $\mathrm{HCl}, \mathrm{pH} 7.5$, the undissolved material excluded, and the supernate dialysed against $2.5 \mathrm{M} \mathrm{NaCl}$ at neutral $\mathrm{pH}$.

Preparation of type II collagen. The cartilagenous parts of tibiae, humeri, and femora were collected at necropsy of fetuses of up to 12 weeks gestation. The perichondrium was removed by careful dissection on ice prior to homogenisation. The majority of the proteoglycans was dissolved by the method of Lohmander by means of repeated guanidine extractions. ${ }^{16}$ The pepsin digestion used to solubilise the collagen followed the method of Miller $^{17}$ with the minor modification of increasing the pepsin concentration to $10 \mathrm{mg} / \mathrm{ml}$. The collagen was precipitated by the addition of crystalline $\mathrm{NaCl}$ to a final concentration of $0.9 \mathrm{M}$, redissolved in $1 \mathrm{M}$ $\mathrm{NaCl}, 0.05 \mathrm{M}$ Tris- $\mathrm{HCl}, \mathrm{pH} 7.5$ at $4^{\circ} \mathrm{C}$, and precipitated twice by dialysis against $0.02 \mathrm{M} \mathrm{Na}_{2} \mathrm{HPO}_{4}$. In the cold this type II collagen was solubilised in $0.2 \mathrm{M} \mathrm{NaCl} 0.05 \mathrm{M}$ Tris- $\mathrm{HCl}, \mathrm{pH} 7.5$ and then passed through a DEAE-cellulose column (DE 52, Whatman Chemicals) to withhold residual proteoglycans. ${ }^{18}$ As assessed by the uronic acid assay, ${ }^{19}$ this final collagen type II preparation was free from proteoglycan contamination.

Preparation of type III collagen. Skin was obtained from babies at necropsy, the subcutaneous fat was scraped off, and the dermis minced together with crushed ice in a meat grinder. The homogenised skin was extracted with $1 \mathrm{M} \mathrm{NaCl}, 0.05 \mathrm{M}$ Tris-HCl, pH $7 \cdot 5$, and with $0.5 \mathrm{M}$ acetic acid at $4^{\circ} \mathrm{C}$, in each case for 2 days, to remove contaminations like serum proteins and fat. The undissolved material was digested with pepsin and chromatographically purified according to the method of Epstein. ${ }^{15}$

Cyanogen bromide cleavage of type II. The $\mathrm{CNBr}$ cleavage of purified type II collagen was carried out as detailed by Epstein. ${ }^{15} \mathrm{CM}$-cellulose (CM-52, Whatman) chromatography of the $\mathrm{CNBr}$ peptides followed the method of Miller. ${ }^{17}$

Collagen analysis. As well as by the chromatographic methods collagens were characterised by SDS-PAGE electrophoresis and amino acid analysis. SDS-PAGE was performed according to the method of Furthmayr and $\mathrm{Timpl}^{20}$ on whole collagen chains using $5 \%$ acrylamide gels. For amino acid analysis samples were hydrolysed in $2 \mathrm{ml}$ of boiling $6 \mathrm{NHCl}$ at $111^{\circ} \mathrm{C}$ for 22 hours under nitrogen in sealed tubes. The acid was removed by vacuum and the samples used for analysis on a Biotronik LD $6000 \mathrm{E}$ with a 4-buffer elution system. Each collagen preparation used in the assays was subjected to the limulus test to quantify its endotoxin content. All preparations were positive for endotoxin, but the small differences-type I $80 \mathrm{ng} / \mathrm{ml}$, type II $40 \mathrm{ng} / \mathrm{ml}$, type III $60 \mathrm{ng} / \mathrm{ml}$-at identical collagen concentrations $-1 \mathrm{mg} / \mathrm{ml}$ - can clearly not account for the striking type-specific effects observed in the assays.

All collagen samples were checked for possible trace contaminants with proteolytic activity with the Bio-Rad Protease Detection Kit. This sensitive assay -it allows measurement of proteases in the range of $1 \mu \mathrm{g} / \mathrm{ml}$-is based on the radial diffusion of enzymes into a thin layer containing casein at physiological pH. A proteolytic contamination of the samples could not be demonstrated for collagen concentrations of $1 \mathrm{mg} / \mathrm{ml}$. 


\section{Results}

INTERACTION OF COLLAGEN TYPE II WITH THE ALTERNATIVE PATHWAY OF THE COMPLEMENT SYSTEM

In experiments to establish the dose-response curve for C3 consumption in normal guinea-pig serum type II was about 10 times more effective- $50 \%$ consumption at $40 \mu \mathrm{g} / \mathrm{ml}$-than type I collagen, while type III was virtually inactive. As no effect of type II on $\mathrm{C} 1, \mathrm{C} 2$, or $\mathrm{C} 4$ could be measured at concentration of up to $100 \mu \mathrm{g} / \mathrm{ml}$, this suggested that antibodies against the human collagen type forming immune complexes and thereby activating the classical pathway were not present in the guinea-pig serum used. This result led us to propose a direct interaction with the alternative pathway. The use of genetically C4-deficient guinea-pig serum confirmed this assumption (Fig. 1). We attribute the small difference in C3 turnover to different kinetics in both sera observed also for other activators of the alternative pathway: at identical concentrations C3 turnover by these substances can be $10 \%-15 \%$ lower in C4-deficient guinea-pig serum than in normal guinea-pig serum, and gives identical results only upon prolongation of the incubation time. ${ }^{21}$ As shown on the right side of Fig. 2, incubation of C4-deficient guinea-pig serum with type II collagen at the routine temperature of the assay produced an $80 \%$ reduction of the haemolytically active C3 molecules. Native and heat denatured collagen gave

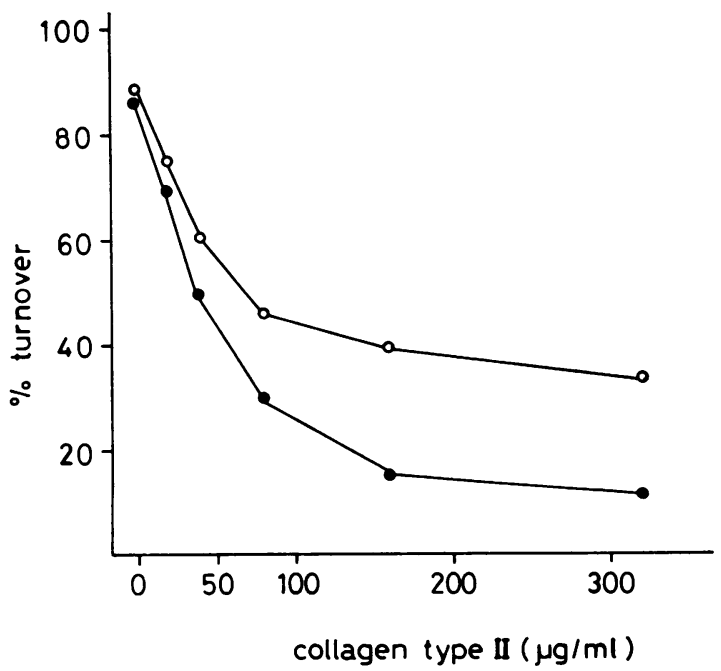

Fig. 1 C3 turnover in normal (๑-) and C4-deficient $(\mathrm{O}-\mathrm{O})$ guinea-pig serum as a function of type II collagen concentrations.

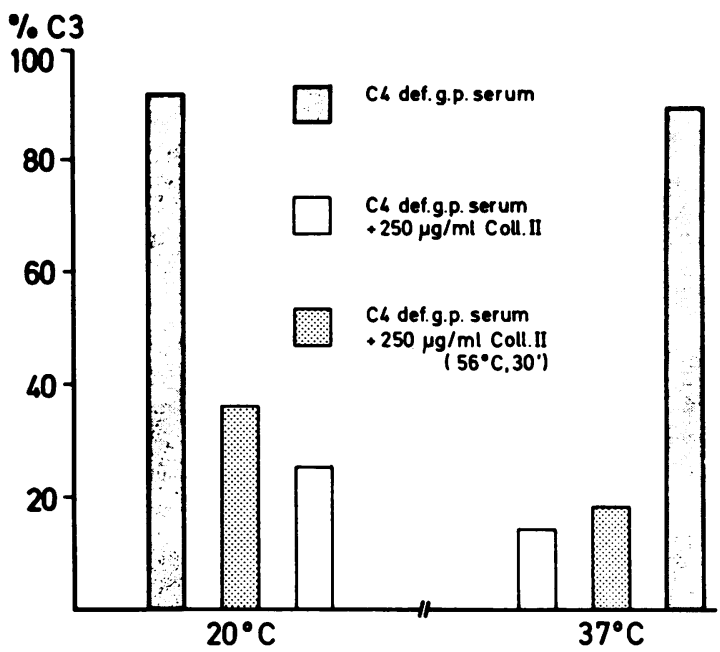

Fig. 2 C3 turnover in C4-deficient guinea-pig (C4-def. g.p.) serum induced by type II collagen (coll. II). At the routine test temperature of $37^{\circ} \mathrm{C}$ (right side) both native and heat-denatured type II collagen give a reduction of the haemolytically available $C 3$ to less than $20 \%$ of the control. To render denaturation of the collagen triple helix during the test period impossible, the same experiment was performed at $20^{\circ} \mathrm{C}$ (left side). Again, the C3 consumption was independent of the type II collagen conformation.

a comparable degree of $\mathrm{C} 3$ turnover, and so this effect was independent of the triple helical conformation.

Collagen has a sharp thermal transition with a $T_{m}$ of about $38^{\circ} \mathrm{C}$ for the triple helix-random coil conversion. ${ }^{1}$ As the routine haemolytic assays for $\mathrm{C} 3$ activity are incubated at $37^{\circ} \mathrm{C}$ for 30 minutes, we had to take special precautions to secure an unaffected triple helical conformation. Accordingly we ran assays at $20^{\circ} \mathrm{C}$, a temperature that maintains the native conformation during the rest period. However, we could not find a dependence of the C3 consumption on the triple helical structure of type II collagen. Deliberate thermal destruction of the native conformation which results in the complete separation of the component $\alpha$ chains-type II lacks intramolecular links-does not show a clear-cut effect on the $\mathrm{C} 3$ depletion at $20^{\circ} \mathrm{C}$; the slightly increased $\mathrm{C} 3$ turnover at $37^{\circ} \mathrm{C}$ can be easily attributed to a direct thermal effect on the enzymes active in the assay (Fig. 2, left side). The finding that the $\mathrm{C} 3$ consumption was not abolished after heat denaturation of type II renders the assumption of a residual C3 cleaving proteolytic activity in the purified collagen samples unlikely.

The data presented above are inconclusive with 
regard to the mechanism of alternative pathway activation by type II collagen. They may simply result from the passive adsorption of $\mathrm{C3}$ to the collagen polypeptide chains, thus producing a diminution of haemolytically available $\mathrm{C} 3$ molecules.

To investigate this possibility the immunoelectrophoretic behaviour of $\mathrm{C} 3$ and factor $\mathrm{B}$ was analysed after incubation of human and C4-deficient guineapig serum with type II $(250 \mu \mathrm{g} / \mathrm{ml}, 30$ minutes $)$. The $\mathrm{Bb}$ determinants located in the respective cleavage products of human factor $\mathrm{B}$ were detected by the specific antiserum employed (Fig. 3). The C3 antiserum revealed the presence of the anodally migrating $\mathrm{C} 3 \mathrm{~b}$ fragment in C4-deficient guinea-pig serum (Fig. 3). In the control both complement components remained in the zymogen form. The conversion of $\mathrm{C} 3$ and factor $\mathrm{B}$ in human serum by type II collagen does not depend on its triple helical conformation as its $\alpha$ chains and the $\mathrm{CNBr}$ peptide mixture, consisting of nonhelical chain fragments of varying length, also mediate the cleavage of $\mathrm{C} 3$ and factor $B$. The activation of both components also was evident in normal and genetically C4-deficient guinea-pig serum. As judged by the alteration of the immunoelectrophoretic behaviour, the effect of types I and III on the conversion of C3 and factor B was less pronounced or absent. Human type II collagen triggers the human APC by promoting the cleavage of $\mathrm{C} 3$ and factor $\mathrm{B}$ to their physiological fragments. The effects of the component $\alpha$ chains and the $\mathrm{CNBr}$ peptides give conclusive evidence to suggest that determinants of the primary structure of type II collagen other than the methionine residues mediate the observed $\mathrm{C} 3$ consumption.

\section{EFFECTS OF HUMAN COLLAGEN TYPE II} ON MOUSE MACROPHAGES

The addition of types I, II, III at different concentrations to the macrophages had striking type specific effects. After 48 hours $100 \mu \mathrm{g} / \mathrm{ml}$ of types I or III had not stimulated macrophages to secrete a tumorolytic principle, and the activity did not differ from that of the nonstimulated control macrophages. However, macrophages incubated with $100 \mu \mathrm{g} / \mathrm{ml}$ type II produced nearly complete target cell destruction. Only type II incubated macrophages developed definite dose-response characteristics (Fig. 4). To elucidate the kinetics of type II generated cytotoxicity macrophages were incubated with 100 $\mu \mathrm{g} / \mathrm{ml}$ type II and their tumorolytic capacity tested at the intervals given in Fig. 5. After 6 hours a definite increase in cytotoxicity was measurable, and after 48 hours the values reached a plateau of nearly $100 \%$ specific lysis. In the controls the alterations were negligible.

Moreover the induced release of lysosomal hydrolases from macrophages was markedly type specific. After 48 hours' exposure to $200 \mu \mathrm{g} / \mathrm{ml}$ collagen the amount of $\beta$-glucuronidase secreted by the type II treated cells was significantly elevated above the

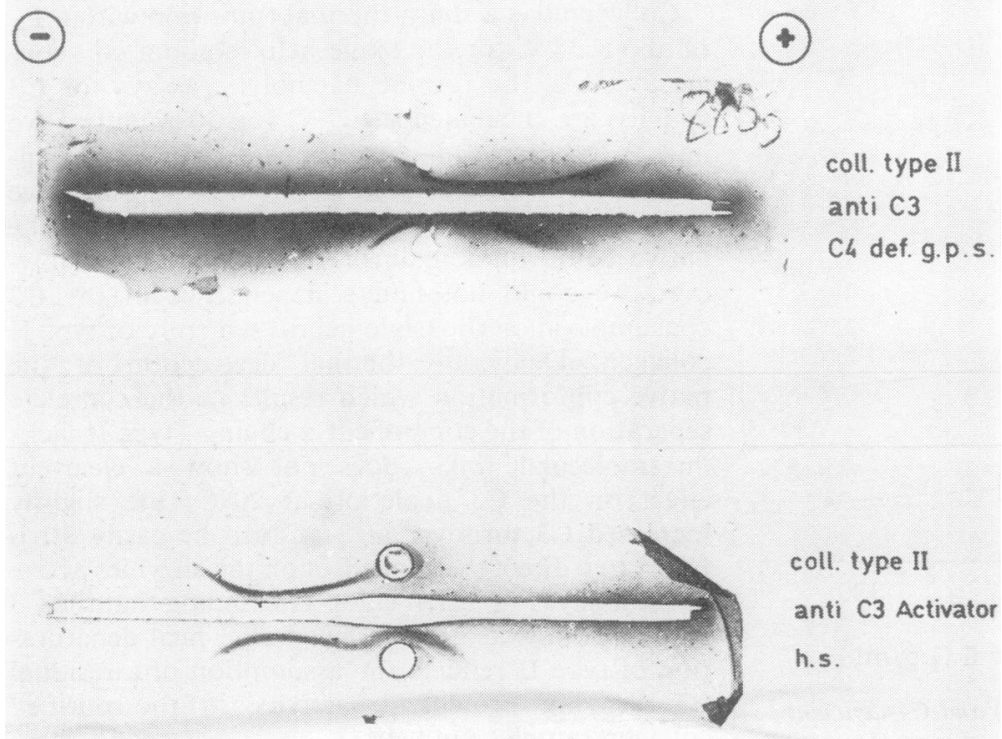

Fig. 3 Immunoelectrophoretic conversion of $\mathrm{C} 3$ in C4-deficient guinea-pig serum (C4-def.g.p.s.) and of factor $B$, that is, $C 3$ activator, in human serum (h.s.) by type II collagen (coll. type II). Above: Generation of anodally migrating C 3 b following incubation of C4- deficient guinea-pig serum with $250 \mathrm{\mu g} / \mathrm{ml}$ type II collagen. Below: Generation of cathodally migrating $B b$ following incubation of human serum with $250 \mu \mathrm{g} / \mathrm{ml}$ type II collagen. A certain amount of $B b$ appeared spontaneously on coagulation. 


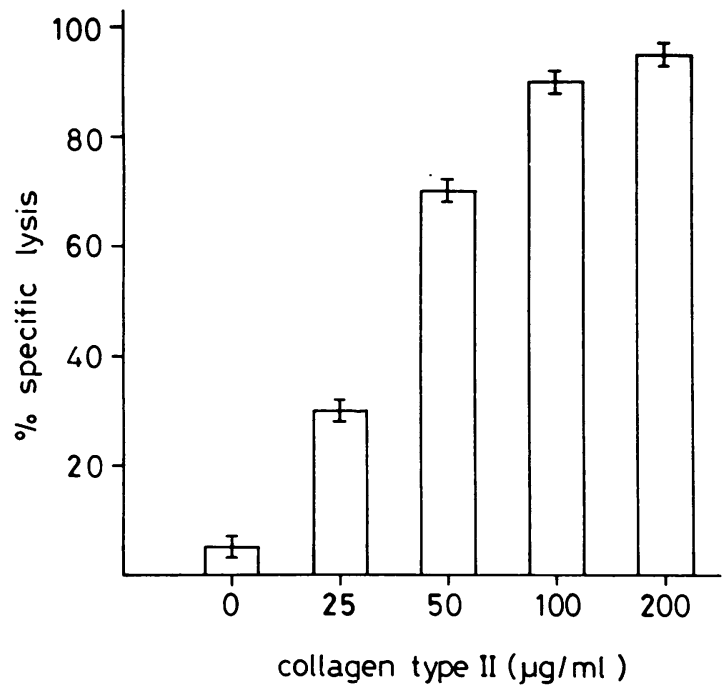

Fig. 4 Lysis of P815 mastocytoma cells by supernatants of macrophages activated in vitro by different concentrations of type II collagen.

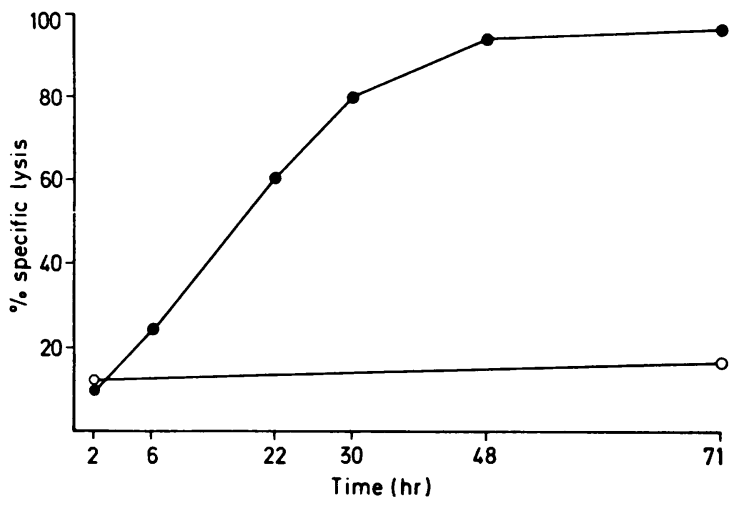

Fig. 5 The time-dependent effect of type II collagenstimulated, mouse-macrophage-mediated cytoxicity against P815 cells $(\bullet-\bullet)$. Controls $(\mathrm{O}-)$ ). Type II collagen concentration: $100 \mu \mathrm{g} / \mathrm{ml}$.

control level. The reaction was dose-dependent (Fig. 6). The type I and type III treated cells, however, displayed neither dose-response characteristics nor an increase in enzyme release. This effect of type II collagen was specific and not associated with release of LDH or morphological signs of cell death. Type II had a pronounced dose-dependent effect on the secretion of another lysosomal enzyme, Nacetyl- $\beta$-D-glucoseaminidase.

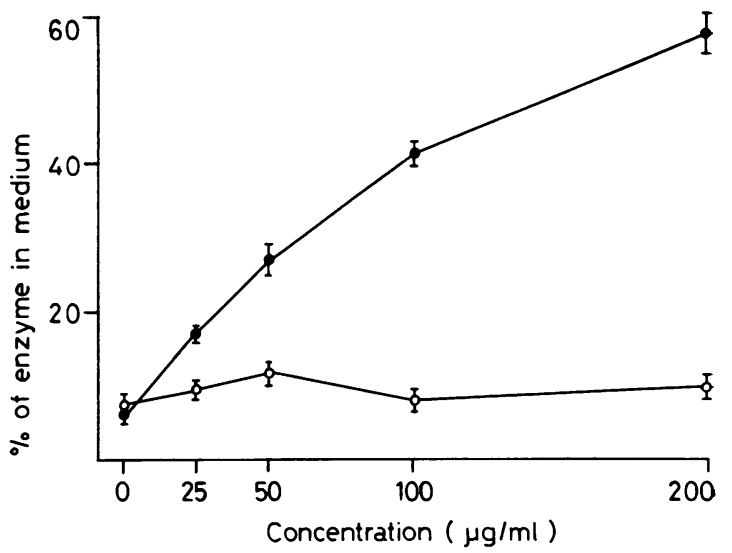

Fig. 6 Specific release of $\beta$-glucuronidase into the culture medium of mouse macrophages after 48 hours' exposure to increasing amounts of type II collagen (-). Release of cytoplasmic LDH in the same cultures $(\mathrm{O}-\mathrm{O})$.

The capacity of type II collagen to induce lysosomal enzyme release was unaffected after $\mathrm{CNBr}$ digestion.

\section{Discussion}

The in-vitro results presented in this paper demonstrate for type II collagen preferentially an activation of the alternative pathway and a stimulation of macrophages to secrete lysosomal enzymes and to become cytotoxic. This effect, unaltered after heat denaturation or $\mathrm{CNBr}$ cleavage, rests on primary structure determinants.

The interaction of the complement system with intersitial collagen has been studied before. Takahashi et al $^{22}$ presented evidence for an activation of the alternative pathway at very high collagen concentrations $(>10 \mathrm{mg} / \mathrm{ml})$, but as their preparations were characterised by the hydroxyproline content only, APC activating or inhibiting contaminations cannot be ruled out. Valet et al..$^{23}$ found that more than $100 \mu \mathrm{g} / \mathrm{ml}$ of purified interstitial collagens were needed for $50 \%$ reduction in the $\mathrm{Cl}$ haemolytic assay, without type differences. Below that concentration we too could not demonstrate an effective activation of the classical pathway. However, our findings clearly indicate that type II collagen in particular can activate the alternative pathway, as exemplified by the studies with C4deficient guinea-pig serum.

Hopper et al. ${ }^{24}$ investigated the interaction of macrophages with type I collagen and reported a dependence on the conformation; denatured collagen 
is bound more easily but internalised more slowly. A functional parameter of mononuclear phagocytes, namely, chemotactic responsiveness, was found to be sensitive in a dose-dependent manner to type I collagen, its component $\alpha$ chains, and $\mathrm{CNBr}$ peptides. ${ }^{25}$ No further collagen types were tested in these studies. Of the different collagen types scrutinised here only type II gave a considerable stimulation of macrophages, as judged by enzyme secretion and generation of cytotoxicity in the supernate.

We found the same pattern of collagen type specificity as Trentham et al. ${ }^{3}$ and Courtenay et al. ${ }^{6}$ in their animal studies on collagen arthritogenicity: type II was the only collagen active in all test systems. With respect to its conformational state, however, the in-vitro and in-vivo effects differed. While the capacity of its component $\alpha$ chains to activate macrophages and the APC remained unaffected, the $\alpha$ chains did not produce arthritis when injected intradermally in complete or incomplete Freund's adjuvant.

Prior to type II collagen a number of substances were reported to activate both the alternative pathway of complement and normal, serum-free cultured macrophages. These substances include streptococcal cell walls, zymosan, and polyanions like carrageenan and dextran sulphate. ${ }^{26}$

After intra-articular injection each of these substances can induce an inflammatory reaction reminiscent of human rheumatoid joint lesions. ${ }^{27-29}$ In view of the parallel effect of type II collagen on macrophages and the APC, which resembles that of these substances, and in view of its arthritogenic potential, the results reported here call for comparison with a number of articular findings in rheumatoid arthritis:

(1) In the rheumatoid synovial membrane large numbers of macrophages are observed, some associated with blastic lymphocytes and even cytoplasmatically bridged to them; fibroblasts close to macrophages frequently display signs of cell damage as shown by vacuolisation, disappearance of cytoplasm, and depletion of nuclear chromatin. ${ }^{30}$ Macrophage-like cells at the cartilage-pannus interface invade and degrade the articular type II collagen matrix. ${ }^{31}$

(2) In the rheumatoid synovial fluid the local production of the representative lysosomal enzymes $\beta$-glucuronidase and $\mathrm{N}$-acetyl- $\beta$ - $\mathrm{D}$-glucoseaminidase is markedly elevated and independent of the white cell counts. ${ }^{13}$ Activation of the complement system by both the classical and the alternative pathway is well documented. ${ }^{78}$ While rheumatoid synovial fluid contains normal or increased amounts of protease inhibitors like $\alpha_{1}$ antitrypsin, $\alpha_{2}$ macroglobulin, ${ }^{32}$ and $\mathrm{Cls}$ inhibitor, ${ }^{33}$ the concentration of the $\mathrm{C} 3 \mathrm{~b}$ inactivator in rheumatoid synovial fluid is significantly reduced in spite of supranormal serum values, ${ }^{34}$ pointing to increased local catabolism and facilitated APC activation due to the diminution of this regulatory protein.

These in-vivo findings in rheumatoid patients show a correlation with the in-vitro effects of type II collagen on macrophages and the APC, which consisted in activation of $\mathbf{C} 3$ and factor $B$, generation of cytotoxicity, and secretion of the lysosomal enzymes $\beta$-glucuronidase and $N$-acetyl- $\beta$-D-glucoseaminidase. While this does not prove a causal connection, our results suggest that type II collagen and its degradation products can mediate a local activation of macrophages and the APC in rheumatoid joints. Once this interaction, possibly initiated by exogenous antigens, ${ }^{35}$ is established on the articular surface, it will not need a persisting agent to run a chronic course and cause extensive injury. It centers on the basic amplification loop of type II collagen-activated macrophages and type II collagen rendered accessible by activated macrophages, as these cells participate in denudation and destruction of cartilage collagen. ${ }^{30} 31$ In this way they also provide for a constant flow of APC-inducing type II collagen material which in turn contributes to complement depletion and enhances inflammatory tissue damage, for example, via C3b activated macrophages. ${ }^{26}$

If not counterpoised completely, the inflammation resulting from this regional deregulation tends to eradicate the type II collagen releasing matrix due to the autocatalytic type II mediated activation of macrophages and the APC, even after the elimination of the inciting agent. Owing to the afferent functions of macrophages and the $\operatorname{APC}^{36}{ }^{37} \mathrm{a}$ smouldering articular type II mediated activation of macrophages and the APC may in turn affect the humoral and cellular responses, culminating in a resetting of autorecognition, a genetic predisposition provided. Indeed, certain HLA D antigens are associated with adult-onset, seropositive rheumatoid arthritis, especially its severe form, ${ }^{38}$ and in mice the susceptibility to type II collagen-induced arthritis appears under $\mathbf{H}$-2-linked control. ${ }^{6}$ This conceptualisation of our results is in keeping with the suggestion by Glynn ${ }^{35}$ that, owing to a genetic susceptibility, a local inflammatory response becomes deregulated in rheumatoid arthritis, leading to a self-perpetuating reaction against components of the immune system and material released by the inflammatory tissue degradation.

Although not the primary event, we suppose that a type II mediated activation of macrophages and the APC might constitute one of the epicentres that perturb the immunological network in rheumatoid 
arthritis. Under normal conditions the establishment of this interaction may be forestalled by the effective control of the APC via the regulatory proteins $\beta 1 \mathrm{H}$ and $\mathrm{C} 3 \mathrm{~b}$ inactivator. More significantly, type II collagen is separated by a manylayered shield from all elements of the immune system: its occurrence is restricted to avascular sites lacking lymphatics. These segregated sites physiologically exclude both egress and access of even low-molecular-weight proteins, a property resting on the molecular sieve effect of the matrix glycosaminoglycan and proteoglycan aggregates. ${ }^{39}$ It is intriguing to see that type II collagen can be found only in these immunologically protected tissues.

We greatly appreciate the outstanding technical assistance of Miss A Börner. H.M. Hanauske-Abel was supported by a grant from the Evariste Galois fund.

\section{References}

1 Bornstein P, Sage H. Structurally distinct collagen types. Ann Rev Biochem 1980; 49: 958-1003.

2 Trentham D E, Townes A S, Kang A H. Autoimmunity to type II collagen: an experimental model of arthritis. $J$ Exp Med 1977; 146: 857-68.

3 Trentham D E, Townes A S, Kang A H, David R J. Humoral and cellular sensitivity to collagen in type II collagen-induced arthritis in rats. $J$ Clin Invest 1978; 61 : 89-96.

4 Stuart J M, Cremer M A, Dixit S N, Kang A H, Townes A S. Collagen-induced arthritis in rats. Comparison of vitreous and cartilage derived collagens. Arthritis Rheum 1979; 22: 347-52.

5 Trentham D E, Dynesius R A, David J R. Passive transfer by cells of type II collagen-induced arthritis in rats. $J$ Clin Invest 1978; 62: 359-66.

6 Courtenay J S, Dallman M J, Dayan A D, Martin A, Mosedale B. Immunisation against heterologous type II collagen induces arthritis in mice. Nature 1980; 283: 666-8.

7 Zvaifler N J. Rheumatoid arthritis. An extravascular immune complex disease. Arthritis Rheum 1974; 17: 297-305.

8 Ruddy S, Fearon D T, Austen K F. Depressed synovial fluid levels of properdin and properdin factor B in patients with rheumatoid arthritis. Arthritis Rheum 1975; 18: 289-95.

9 Munthe E, Høyerall H M, Frøland S S, Mellbye O J, Kass E, Natvig J B. Evidence for complement activation by the alternative pathway in the arthritis of hypogammaglobulinemic patients. Rheumatology 1975; 6: 43-51.

10 Bitter-Suermann D, Hadding U, Melchert F, Wellensiek H J. Independent and consecutive activation of C5, C6, and $\mathrm{C} 7$ in immune hemolysis. 1. Preparation of EAC1-5 with purified guinea pig $\mathrm{C} 3$ and $\mathrm{C5}$. Immunochemistry 1970; 17: 955-62.

11 Müller W, Hanauske-Abel H M, Loos M. Biosynthesis of the first component of complement by human and guinea pig peritoneal macrophages: evidence for an independent production of the $\mathrm{Cl}$ subunits. $J$ Immunol 1978 ; 121 : 1578-84.
12 Bergmeyer H U, Bernt E. Lactat-Dehydrogenase. In: Bergmeyer H U, ed. Methoden der enzymatischen Analyse. Weinheim: Verlag Chemie, 1970: 533-41.

13 Stephens R W, Gosh P, Taylor T K F, Gale C A, Swann $J$ C, Robinson R G, Webb J. The origins and relative distribution of polysaccharidases in rheumatoid and osteoarthritis fluids. J Rheumatol 1975; 2: 393-400.

14 Bitter-Suermann D, Becker S, Meuer S, Schorlemmer H U, Hadding U, Andreatta R. Comparative study on biological effects of the guinea pig complement-peptide $\mathrm{C} 3 \mathrm{a}$ and C3a-related synthesic oligopeptides. Mol Immunol 1980; 17: 1257-61.

15 Epstein E H. $[\alpha 1 \text { (III) }]^{3}$ human skin collagen. $J$ Biol Chem 1974; 249: 3225-31.

16 Lohmander S. Proteoglycans of guinea pig costal cartilage. Eur J Biochem 1975; 57: 549-59.

17 Miller E J. Structural studies on cartilage collagen employing limited cleavage and solubilisation with pepsin. Biochemistry 1972; 11 : 4903-9.

18 Miller E J. Isolation and characterization of a collagen from chick cartilage containing three identical $\alpha$ chains. Biochemistry 1971; 10: 1652-8.

19 Bitter T, Muir H M. A modified uronic acid carbazole reaction. Anal Biochem 1962; 4: 330-6.

20 Furthmayr H, Timpl R. Characterization of collagen peptides by sodium dodecylsulfate-polyacrylamide electrophoresis. Anal Biochem 1971; 41 : 510-6.

21 Burger R. Sulfatierte Dextrane als Aktivatoren des Komplementsystems. Doctorial Thesis at the Technische Hochschule, Darmstadt D 1976; 17: 1-89.

22 Takahashi M, Kawachi-Takahashi S, Matsuura M. Interaction of collagen with serum complement: inhibition of complement-mediated hemolysis. Int Archs Allergy Appl Immunol 1975; 48: 642-52.

23 Valet $\mathrm{H}$, Kahle $\mathrm{H}$, Timpl R. Inhibition of the $\mathrm{Cl}$ complement molecule by collagen and procollagen peptides. Immunobiology 1978; 155: 71 .

24 Hopper K E, Adelmann B C, Gentner G, Gay S. Recognition by guinea pig peritoneal exsudate cells of conformationally different states of the collagen molecule. Immunology 1976; 30: 249-59.

25 Postlethwaite A E, Kang A H. Collagen and collagen peptide-induced chemotaxis of human blood monocytes. J Exp Med 1976; 143: 1299-307.

26 Schorlemmer H U, Bitter-Suermann D, Allison A C. Complement activation by the alternative pathway and macrophage enzyme secretion in the pathogenesis of chronic inflammation. Immunology $1977 ; 32$ : 929-40.

27 Schwab J H, Cromartie W J, Ohanian S H. Association of experimental chronic arthritis with the persistance of Group A streptococcal cell walls in the articular tissue. J Bacteriol 1967; 94: 1728-35.

28 Kaystone E C, Schorlemmer H U, Pope C, Allison A C. Zymosan-induced arthritis. A model of chronic proliferative arthritis following activation of the alternative pathway of complement. Arthritis Rheum 1977; 20: 1396-401.

29 Carmichael D J, Gillard G C, Lowther D A, Handley C J, Santer V B. Carrageenin-induced arthritis. IV. Rate changes in cartilage matrix proteoglycan synthesis. Arthritis Rheum 1977; 20: 834-40.

30 Ishikawa $\mathrm{H}$, Ziff $\mathrm{M}$. Electronmicroscopic observations of immunoreactive cells in the rheumatoid synovial membrane. Arthritis Rheum 1976; 19: 1-14.

31 Harris E D, Glauert A M, Murley A H G. Intracellular collagen fibers at the pannus-cartilage junction in rheumatoid arthritis. Arthritis Rheum 1977; 20: 657-65. 


\section{Hanauske-Abel, Pontz, Schorlemmer}

32 Shtacher G, Maayan R, Feinstein G. Protease inhibitors in human synovial fluid. Biochim Biophys Acta 1973; 303: $138-47$.

33 Hedberg $\mathrm{H}$, Laurell A B. The concentrations of the fourth component of complement and of the $\mathrm{C} 1$ inactivator in synovial fluid from arthritis patients. Clin Exp Immunol 1972; 11: 201-8.

34 Whaley $\mathrm{K}$, Schur P H, Ruddy S. C3b inactivator in the rheumatic diseases. $J$ Clin Invest 1976; 57: 1557-63.

35 Glynn L E. Experimental models and etiology of inflammatory rheumatic diseases. Scand $J$ Rheumatol 1975; 5: suppl 12: 55-62.
36 Symposium: Macrophage functions in immunity. Fed Proc 1978; 37: 77-103.

37 Klaus G G B, Humphrey J H. The generation of memory cells. I. The role of $\mathrm{C} 3$ in the generation of $\mathrm{B}$ memory cells. Immunology 1977; 33: 31-9.

38 Rossen R D, Brewer E J, Sharp R M, Ott J, Templeton $\mathrm{J}$ W. Familial rheumatoid arthritis. J Clin Invest 1980; 65: $629-42$.

39 Stockwell R A. Biology of Cartilage Cells. Cambridge: Cambridge University Press, 1979: 30-1 ; 71-2. 